\title{
EDUCATIONAL MIGRATION IN TERMS OF GLOBAL AND NATIONAL CHALLENGES
}

\section{Svitlana Luchyk}

Chernivtsi Institute of Trade and Economics of Kyiv National University of Trade and Economics, Faculty of Accounting, Finance and Economic Activities, Chernivtsi, Ukraine

\section{Vasil Luchyk}

Chernivtsi Institute of Trade and Economics of Kyiv National University of Trade and Economics, Faculty of Accounting, Finance and Economic Activities, Chernivtsi, Ukraine

\section{Margaryta Luchyk}

Kyiv Cooperative Institute of Business and Law, Economics and Law Faculty, Kyiv, Ukraine

CMESTE

JEL Category: J11, I23, F66

\begin{abstract}
The article deals with the problems of the expansion of international educational migration in modern conditions. It is emphasized that the economy of many countries in the world is facing the problems of loss of educated youth and the growing demand for attracted educated immigrants. Higher education in countries is considered as an area of increasing exports of educational services and a factor of attracting prospective international students as potential specialists for the national economy. Educational migration and academic mobility have been identified as forms of educational migration. Factors of influence on the increase of intensity of international educational migration are established. The authors study the main trends of educational migration flows from the point of view of their impact on both donor and host countries. The dynamics of the number of students entering and leaving the borders of some developed countries are given. It is emphasized that at the present stage of development of the world economy of the country there is a fiercely competitive struggle for young, initiative personnel. Therefore, governments are making changes to the laws of countries to improve the conditions of study, accommodation, and adaptation of foreign students. On the other hand, the authors emphasize the contradictory impact of migration capital on the economy of donor countries. Based on the example of Ukraine, the article analyzes national trends in educational migration. The causes of the widespread educational migration in the country are identified.

Address of the corresponding author:

Svitlana Luchyk

部lluchiksvitlana@gmail.com

This is, first, a difficult socio-economic situation in the country, a decline in the quality of national education, an increase in external educational
\end{abstract}


migration. The dynamics of the recent flow of international mobility in Ukraine and the main directions of the direction of the educational migration of Ukrainians are presented. The necessity of state regulation is determined and the main directions of regulation of educational migration in Ukraine in the interests of preservation and development of intellectual capital and securing of competitive positions in the international market of educational services are outlined.

Keywords: globalization, internationalization of higher education, educational migration, academic mobility, foreign student, loss of intellectual capital

\section{INTRODUCTION}

Currently, globalization is a major trend in the development of various spheres, including politics, economy, and education. Opening borders and labor markets, reducing the cost of transport and communications are leading to increased mobility between countries. A characteristic tendency of the development of the modern education system is its internationalization and rapid growth of student migration.

Graduates of educational institutions under current conditions act as one of the most mobile population groups. Their migration intentions are less dependent on the circumstances. Unburdened by social obligations, young people are ready to travel from the regions to receive education in prestigious universities in the country and abroad. Thus, regions and countries lose talented youth, and as a result, there is a risk of significant loss of human capital. According to official data from TSN.ua (TSN.ua, 2019), about 70 thousand Ukrainian students study abroad. About $40 \%$ of them are educated in Poland. 55\% of foreign students in Poland are Ukrainians, according to a survey by Selective.

Considering the state of general globalization and internationalization of the world space, it can be stated that migration is becoming one of the most important characteristics of the development of modern society. Usually, migratory flows are divided according to their goals into two types: economic and social. Social migration may include marital migration, educational and training migration, religious migration (pilgrimage), family reunification, tourism, recreation and treatment, ethnic migration, repatriation.

\section{INTERNATIONALIZATION OF HIGHER EDUCATION: THEORETICAL ASPECT}

The Law of Ukraine "On Higher Education" (Vidomosti Verkhovnoyi Rady of Ukraine, 2014), adopted in 2014, declared international integration and integration of the national higher education system into the European educational space one of the main principles of public policy in education. In the field of international cooperation, the Law identified twelve areas of activity for universities, including participation in exchange programs for students, teachers and researchers, the organization of international scientific events, etc.

Thus, educational and training migration is driven by the need to receive education and training.

According to Semiv (2013), the current stage of globalization, the Europeanisation of socioeconomic processes and phenomena has defined educational migration as a meaningful, intellectually meaningful form of population migration. The possibility of free choice of a place of study for students' self-realization forms the basis for increasing the level and volume of interand intra-regional educational mobility. Other scholars (Filatov \& Romashova) state that, on the one hand (from the point of arrival/departure territory), educational migration can be considered as a set of displacements of educational migrants, and on the other (from the position of an educational migrant) as a set of displacements to achieve the goal of migration.

Roshchin (Roshchin, 2010) offers to understand educational migration as one of the types of migration - the spatial displacement of people directly involved in the process of intellectual emigration. According to his interpretation, educational migration leads to the "leakage of young brains", if it becomes irreversible. 
Educational migration is a broader concept than educational migration. Educational migration involves the educational activities of students studying under the bachelor's degree program, a master's degree program in a foreign university, conditioned by obtaining higher professional education based on generally accepted norms and rules of international educational activity. Educational migration also includes various internships, additional education, courses, and other forms of advanced training.

\subsection{Academic mobility as a form of educational migration}

To refer to the processes of moving people for research and academic education, the terms of cross-border education and academic mobility related to educational migration are additionally used in the expert environment. In the Law of Ukraine "On Higher Education" (Vidomosti Verkhovnoyi Rady of Ukraine, 2014), academic mobility is defined as an opportunity for participants of the educational process to study, teach, internship or pursue the scientific activity in another higher education institution (scientific institution) on the territory of Ukraine or abroad. Higher education applicants who apply the right to academic mobility during their studies, internships or scientific activities in another higher education institution (scientific institution) in the territory of Ukraine or abroad are guaranteed to maintain their place of study and receive a scholarship by the provisions on the application of the right to academic mobility. Such people are not deducted from higher education applicants. The documents of the Bologna Process, of which Ukraine has been a participant since 2005, distinguish between two types of academic mobility: vertical and horizontal. Vertical is interpreted as a full study of a student in a foreign university, and horizontal - as a study for a limited period. Crossborder education means (Kaleniuk, 2008) "all types of higher education programs or other types of educational services where their consumers (students) reside outside the country of origin of the educational organization providing the diploma."

Most professionals consider academic mobility and cross-border education to be the main institutional forms of educational migration, as the former involves moving between academic institutions and the latter between countries (including distance learning) in the educational process.

\subsection{Factors influencing the formation and intensity of educational migration}

The educational migration according to Katrovsky (Katrovsky, 2003) can be divided into three stages: preparatory, core and final. The preparatory stage of educational migration involves the formation of territorial mobility. This may include the formation of an information package on educational migration opportunities. For example, analysis of the general (demographic, economic, political) characteristics of the selected region and features of migration processes in it; problems (needs) of higher education institutions in the region); remote examination; previous acquaintance with the training programs; search for financial resources for education and living in the region where the educational process takes place, etc.

At the core stage of migration, the process of relocation and the related registration with law enforcement agencies and educational institutions, search for a place of residence and further occupation, preliminary acquaintance with the teaching staff and classmates (groupmates, colleagues), etc., take place.

The final stage involves adapting students to a new place of residence, to the population, to the educational process, and to solving many problems associated with it.

Educational migration today, according to Volokh \& Grishaev, has a high degree of intensity, due to the following objective factors:

- enhancing the integration of education systems driven by the needs of global politics and the economy;

- increasing the importance of education as a result of the transition to information society (knowledge society);

- the need for continuing education and continuous training in response to increasing competition in the labor market;

- development of information technologies that allow educational institutions to increase their 
information openness, increase the accessibility of their services to potential students;

- the orientation of the educational policy of many countries to the intensification of educational migration, increase of accessibility of educational services, internationalization of educational environment.

- the creation and effective functioning of international student exchange programs such as Erasmus, Erasmus Mundus, etc.

\section{INTERNATIONAL EDUCATIONAL LABOR MIGRATION: CURRENT TRENDS AND CHALLENGES}

UNESCO defines the category of foreign students as persons who have been allowed to undertake a specific program of study in institutions and schools of a country of which they are not nationals. Such migration is classified as temporary, limited by the amount of time it takes to complete the course. Migrants typically receive special student (non-immigrant) visas that entitle them to enter the country with their family members and limited employment opportunities.

Educational migration can be considered as a positive and negative factor for the development of the country.

In the context of increased migration flows worldwide, educational migrants can be considered as the most desirable category, as it is composed of young and initiative people who are open and willing to embrace new knowledge and technology. They adapt quickly to the local labor market and adapt to the linguistic and cultural environment.

The leader in the global education market is the United States, which enrolled 964,897,000 international students in 2017, accounting for about one-fifth of all international educational migrants. The top five also included: The United Kingdom (8.2\%), Australia (7.2\%), Germany, France $(4.9 \%$ each), the Russian Federation $(4.7 \%)$. This is practically half of all international students. Countries such as Canada, Japan, China, Turkey, Italy, and Spain are successfully competing with the leading countries in the field of educational migration. The global educational space has greatly accelerated student movements towards universities in countries such as Malaysia, Singapore, Egypt, Saudi Arabia, United Arab Emirates.

According to UNESCO-UIS (UNESCO-UIS, 2019), 3302.3 thousand foreign students enrolled in high-income countries in 2017. There are 2107.3 thousand educational migrants in European countries.

Not to mention the reverse movement of students, even from the leading countries. According to 2017 data, 976,000 people went to Europe to study, 928 people from China, 390,5 people from Africa, and 332 from India. Much less young people went to study in Germany (122.2 thousand people), France (89.4 thousand people), the USA (86.6 thousand people), Italy (74.3 thousand people), Spain ( 41,4 thousand), Slovakia $(32,4$ thousand) (Fig. 1).

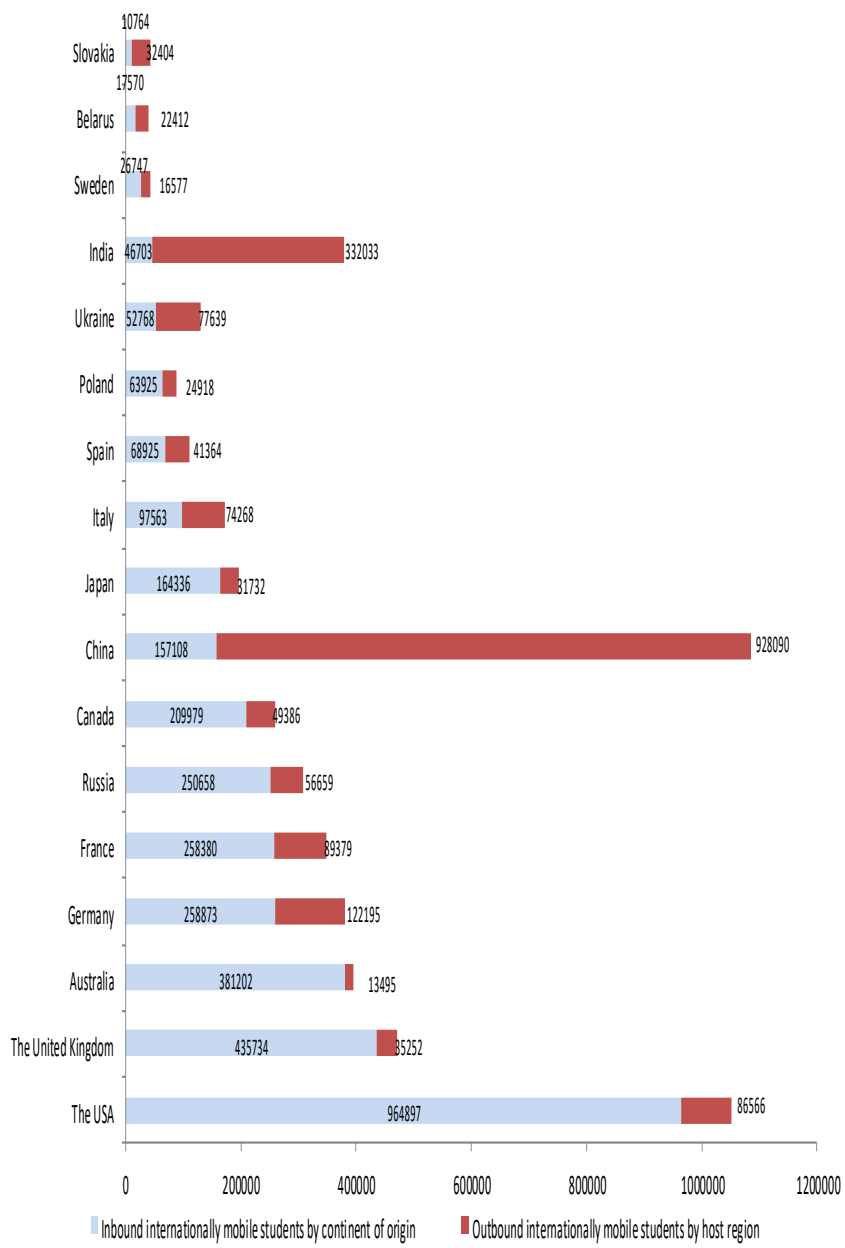

Fig. 1 Trends in the world of education: the number of inbound and outbound students (UNESCO-UIS, 2019) 
Thus, according to the UNESCO forecast, by 2025 the number of foreign students will reach 7 million (UNESCO-UIS, 2019).

By 2020, China plans to become Asia's most attractive destination for international students. 500,000 foreign students are expected to study at higher educational establishments in the PRC. At the end of the twentieth century, China implemented a reform of higher education. As a result, in 2019, 40 Chinese universities entered the QS World University Rankings. Six Chinese universities are in the top 100 list. Moreover, in the ranking of the best universities in developing countries Times Higher Education (THE) in 2019, 72 Chinese universities, and 4 of them occupy leading positions. For example, in this rating, Russia is represented by 35 higher education institutions, the best of which, Moscow State University. Lomonosov, placed on the fifth step (Kapalina, 2019).

In Presidential Decree \# 204 of the Russian Federation V. Putin from May 7, 2018 "On national goals and strategic objectives of the Russian Federation for the period up to 2024" (Decree of the President of the Russian Federation, 2018) formulated state setting by 2025 to prove the number of foreign students enrolled in higher education educational institutions up to seven hundred and ten thousand people.

Student youth is the most active social group. It is easier than other segments of the population to adapt to new living conditions. International students who stay after graduation in the host country increase its socio-demographic potential. During their studies, they learn the language, become familiar with the local culture, and generally become sufficiently adapted to the national labor market. Educational migration, in this case, allows compensating for the negative consequences of depopulation and aging of the population by replenishing the labor market by workers of working age, in particular, specialists in the field of information technology, science, health care, education, etc.

For host countries, educational migration is a potential source of labor, contributing to a change in GDP, as well as a significant resource for the educational services market, currently estimated at $\$ 60-65$ billion, including $40 \%$ of the US and UK. This amount includes tuition, accommodation, transportation and other expenses for foreign students, interns and graduate students. The education market is projected to reach $\$ 90$ billion. Exports of educational services have already brought about $\$ 30$ billion to OECD countries, accounting for $3 \%$ of total services trade. For example, in Australia, revenue from trade in services and goods related to education is the third most important export item of services, accounting for $12 \%$ of its volume.

The structure of the social relations of foreign students includes not only regular contact with the local population, classmates, and teachers. It also brings together scientific, academic and professional relationships. Support for international educational migration can be seen as a way of influencing the formation of the future elite in donor countries and as a form of investment that has a multiplier effect in the medium term. Through students studying in foreign countries, donor and recipient countries are much more effective in enhancing cooperation with one another.

Thus, the internationalization of higher education provides maximum economic benefits in a short timeframe, strengthening the country's geopolitical position. So, for the 2013-2014 academic year, France earned 1.5 times more than allocated for the study of foreign students. In particular, the state spent $\$ 3.5$ billion on scholarships and subsidies and paid $\$ 5.4$ billion for accommodation, travel, and travel. In 20142015 in the UK, international students paid about $\$ 4.8$ billion for education, spending another $\$ 5.4$ billion on various goods and services in the country, supporting 207,000 jobs (lbraev, 2018). Revenues from enrollment in Russian universities of foreign students (5top100.ru, 2018) amounted to more than 84 million rubles in 2017, in 2018 more than 96 million rubles.

It should be noted that the export of education services is not just about the extra income. For example, the average cost of studying for foreigners in the US is close to $\$ 30,000$, but more strategically, it is important for high school leaders to increase their awareness in the world and integrate the best practices of foreign education into learning processes. That is, with the growth of the total number of mobile students, the direction of international education has changed: now it is 
not only an integral part of large exports but also an important component of diplomacy, trade policy, as well as intercultural ties between different countries, which reflects current trends in social development.

In 2017, Ukraine ranked 44th in the ranking of countries in the index of education development index 0.794 . Fig. 2 presents the dynamics of the number of students from Ukraine who studied during 2013-2017 abroad, as well as foreign students who studied in this period in Ukraine.

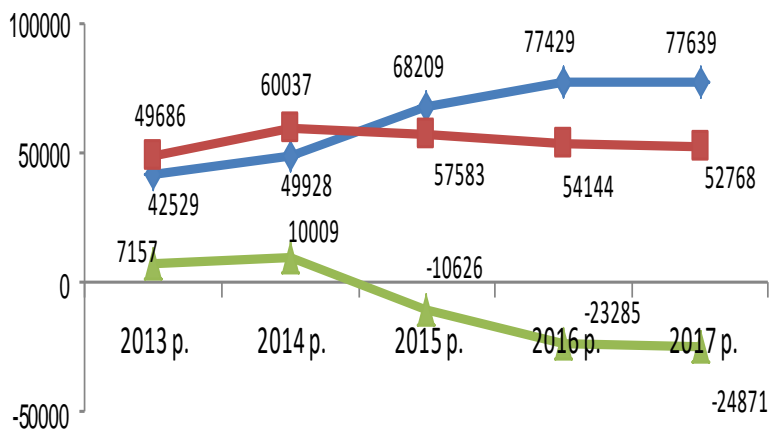

$\rightarrow$ The students from Ukraine who studied abroad, persons

-The intemational students who studied in Ukraine, persons

Fig. 2. The net flow of international mobility in Ukraine in 2013-2017 (Ministry of Education and Science of Ukraine, 2019)

In 2018, 75,605 international students were studying at higher education institutions in Ukraine. Among them are students from 154 countries, including India $(19.8 \%$ of total students), Morocco (9.8\%), Azerbaijan (8.2\%), Turkmenistan $(6.7 \%)$, Nigeria $(4,7 \%)$ and other countries (Ministry of Education and Science of Ukraine, 2019). Foreign students study in Ukraine at 443 higher education institutions in such specialties as "Aviation and rocket technology", "Applied physics and nanotechnology", "Gas and petroleum engineering and technology", "Shipbuilding", "Atomic energy research", Agronomy, Biology, and Genetics. However, the most popular is the specialty "Medicine and Pharmacology". The most popular medical universities among foreign students are Kharkiv National Medical University, Odessa National Medical University, National University named O. Bogomolets (Kyiv) and others. In Chernivtsi, foreign students are trained by the Bukovyna State Medical University. In 2018, 1,723 students studied there.
The overwhelming majority of foreign students receive higher education in Ukraine as their primary education (87.5\%). However, there are $9.5 \%$ of those who came to study the language (language training), to receive the second higher education (postgraduate education) $-2.0 \%$ and to study in postgraduate or doctoral studies $-0.9 \%$.

According to Expat Insider 2016, Ukraine has become the most affordable country in terms of living expenses, ranking second in terms of personal financial satisfaction (Ministry of Education and Science of Ukraine, 2019).

Consequently, the number of foreign entrants seeking Ukrainian education is increasing every year. Young people are attracted to easy access to Ukrainian universities, relatively low cost of living and studying at the university and our country's proximity to Europe.

However, there are some problems. Regarding the quality of education, it should be noted that in the world ranking of the best Times 2018 universities (Chundak, 2018), our universities have dropped to $800-1100$ positions out of a total of 1102 . In total, only five national educational institutions are ranked. This situation may be justified by the lack of funding for national higher education institutions, the inability of teaching staff and students to participate in international scientific projects due to high competition and other reasons.

It is impossible not to mention the problematic circumstances that foreign students face when starting their studies in Ukraine. First, it is communication in a foreign language. The level of adaptation of students depends on the speed of mastering their state language. Foreign students need to spend a lot more time studying. Besides mastering the oral and written language, they need to learn a written academic culture to be able to perform scientific research, prepare individual and independent assignments. Also, they must lead an independent life, including solving household problems, attending shopping and leisure facilities, etc., which also requires a knowledge of the language. The culture of food consumption and the rules of behavior at catering establishments in all countries are different, and it will take a long time for a foreigner to become accustomed to foreign characteristics. 
A significant problem for international students may be living conditions in university dormitories. The quality of residential services provided in hostels leaves much to be desired. A large number of people complain about the lack of repair and accommodation in one room.

Last but not least, the financial side plays a role in the number of problems of foreign students. In Ukraine, foreigners only study on a contractual basis. Therefore, they often lack the resources to pay for their education and to maintain a normal standard of living. They are usually not permitted to receive loans or other financial assistance. It is also very unlikely that a foreigner is legally able to get a job.

Foreign students may have another problem social. The study found that most international students are quite sociable and have a wide range of communication. However, they are still far from home, and therefore far from relatives and relatives. Also, such loneliness sometimes even leads to depression.

Let us now evaluate the trends of educational migration of Ukrainian youth.

Dissatisfaction with the quality of national education, the lack of the need to enter a foreign university as a result of external education evaluation, the desire to obtain a foreign diploma, stay to live and work in another country, these and other reasons are pushing Ukrainian youth to go abroad. For the period 2013-2017, the number of Ukrainian students studying abroad increased by 35,110 students, or by $82.6 \%$.

Most often, Ukrainians choose higher education institutions in Poland, the Czech Republic, and Germany. Currently, about 40,000 students from Ukraine study in Poland. Poland is close to Ukrainians in territorial and cultural terms. The similarity of mindsets between countries, the availability of Polish language learning, makes it easier and faster for our students to adapt to universities. On, special scholarships and grants allow students to study for free.

Ukrainian students chose Germany because there is an opportunity to study for free or at a reasonable cost. There is an opportunity to receive a scholarship. According to many young people, the German universities provide quality education and high professional knowledge. They also provide students with comfortable living conditions.

The number of Ukrainians studying at universities in the Czech Republic and Slovakia is increasing every year. The Czech Republic also provides an opportunity to study for free, especially for students who choose the Czech language curricula. The number of young people who want to study in Slovakia has increased significantly. If less than 400 Ukrainian citizens studied there in 2016, then in 2018 - nearly one and a half thousand.

More and more Ukrainians are choosing universities in Spain, Italy, Canada, Austria, the United Kingdom, France, and other countries.

However, it should be noted that educational migration is widespread and in this case, has a negative context for the state. Today, student youth migration is particularly strong as youth is the most mobile population. Student youth, who have not been able to socialize and adapt within the university, leave the country for further adaptation abroad, while coping well with this and leaving their homeland forever. That is, Ukrainians use education as a way to emigrate from the country. This is a very dangerous phenomenon. It is actually a loss of the intellectual potential of the country. Moreover, the state does not take any measures to return young people, for example, it does not create attractive jobs. For 13 years, 250,000 young highly qualified people have left Ukraine. These are carriers and producers of new knowledge.

\section{CONCLUSIONS}

Thus, international educational migration is the displacement of people between countries to receive education at different levels and at different times. These include the movement of students, secondary and post-secondary students, postgraduates, doctoral students, and trainees, professionals upgrading their qualifications in different educational institutions, structures, and companies. An integral part of educational migration is the flow of educational migrants, which are oriented to educational institutions (colleges and universities). The standardization of educational programs and the increasing availability of foreign training courses help to increase the number of students interested 
in obtaining a foreign diploma. Thus, modern education is becoming cross-border, characterized by increased mobility of students and teachers. Most of them believe that their education will promote career development, allow them to find a job in their chosen country and possibly obtain a permanent residence permit.

Student migration today is the best way to attract young, active, initiative and highly qualified people who are open and willing to embrace new knowledge and technology. At the present stage of the development of the world economy, the countries are fiercely competitive for skilled labor. However, the massive departure of young people abroad, and most importantly their unwillingness to return, poses a great danger to the state, which can lead to loss of intellectual capital of the country. If society is unable to provide young people with work, then there is no future. Youth and their most active part - students do not want to live in a developing country, they seek to live in a progressively developed society, to feel the need for self-fulfillment and career growth.

\section{WORKS CITED}

5top100.ru (2018, December 10) Rossiya vklyuchayetsya $v$ konkurentsiyu za inostrannykh studentov Retrieved December 10, 2018, from https://5top100.ru/en/news/93717/.

Chundak, A. (2018, August 25) Laskavo prosymo: yak inozemtsi yidut' na navchannya do Ukrayiny. Studway.com.ua. Retrieved from https://studway.com.ua/inozemtsi-v-ukraini/.

Decree of the President of the Russian Federation №204 (2018, May 07) On the national goals and strategic objectives of the development of the Russian Federation for the period until 2024. Retrieved from http://www.kremlin.ru/events/president/news/57425.

Filatov, V.M., \& Romashova, J.V. (2014) Specific features of educational migration and its place in the structure of migration flows. An efficient economy, 2. Retrieved from http://nbuv.gov.ua/UJRN/efek_2014_2_63.

Ibraev, I. (2018, August 29). Global trends in higher education. Zebra.today. Retrieved from https://zebra.today/i508.

Kaleniuk, I. (2008). Higher education in today's global environment. High school, 9, 55-62.

Kapalina, S. (2019, March 03) Vostochnaya mudrost': zachem uchit'sya v Kitaye i zhdut li tam inostrantsev. Forbes.ru. Retrieved from https://www.forbes.ru/forbeslife/.

Katrovsky, A. (2003, August) Migration to study as a socio-geographical process. Poster session presented at the International School-Seminar (3-22 August 2003) - International SchoolSeminar (pp. 108-115). Smolensk: Universum.

Law of Ukraine On Higher Education №1556-VII (2014, July 1). Vidomosti Verkhovnoyi Rady of Ukraine, 37-39.

Ministry of Education and Science of Ukraine. State Enterprise "Ukrainian State Center for International Education" (2019) International students in Ukraine. Retrieved from https://studyinukraine.gov.ua/zhittya-v-ukraini/inozemni-studenti-v-ukraini/.

Roshchin, Yu. V.(2010). Emigration of the population. Moscow: State University of Management, 206.

Semiv, L.K. (2013) Educational migration as a factor in the development of territorial migration systems. Socio-economic problems of the modern period of Ukraine, 3, 244-253.

TSN.UA (2019). Every year in Poland, the number of Ukrainian students increases: what attracts education abroad. Retrieved March 26, 2019, from https://tsn.ua/ukrayina/. 
UIS Statistics - Unesco (2019) Education: International student mobility in tertiary education. UNESCO-UIS. Retrieved from http://data.uis.unesco.org. (Last accessed: 15.12.2019).

Volokh, V.A., \& Grishaev S.A. (2017) International educational migration in modern Russia: features, problems, and prospects. Social Policy and Sociology, Vol.16, 1(120), 80-87. Retrieved from http://www.migimo.ru/razdel/153/.

Received for publication: $\quad 26.12 .2019$

Revision received: $\quad 08.01 .2020$

Accepted for publication: $\quad 10.01 .2020$

\section{How to cite this article?}

Style - APA Sixth Edition:

Luchyk, S., Luchyk, V., \& Luchyk, M. (2020, January 15). Educational migration in terms of global and national challenges. (Z. Cekerevac, Ed.) MEST Journal, 8(1), 75-83. doi:10.12709/mest.08.08.01.09

Style - Chicago Sixteenth Edition:

Luchyk, Svitlana, Vasil Luchyk, and Margaryta Luchyk. 2020. "Educational migration in terms of global and national challenges." Edited by Zoran Cekerevac. MEST Journal (MESTE) 8 (1): 75-83. doi:10.12709/mest.08.08.01.09.

Style - GOST Name Sort:

Luchyk Svitlana, Luchyk Vasil and Luchyk Margaryta Educational migration in terms of global and national challenges [Journal] // MEST Journal / ed. Cekerevac Zoran. - Belgrade - Toronto : MESTE, January 15, 2020. - 1 : Vol. 8. - pp. 75-83.

Style - Harvard Anglia:

Luchyk, S., Luchyk, V. \& Luchyk, M., 2020. Educational migration in terms of global and national challenges. MEST Journal, 15 January, 8(1), pp. 75-83.

Style - ISO 690 Numerical Reference:

Educational migration in terms of global and national challenges. Luchyk, Svitlana, Luchyk, Vasil and Luchyk, Margaryta. [ed.] Zoran Cekerevac. 1, Belgrade - Toronto : MESTE, January 15, 2020, MEST Journal, Vol. 8, pp. 75-83. 